\title{
A CRITICAL COMPARATIVE LAW ANALYSIS ON CHALLENGING ANTI- HOMOSEXUAL LEGISLATION IN UGANDA
}

\author{
Patricia Liola Tona Katto*
}

\begin{abstract}
Globalisation has enabled Western countries and international organisations to use donor sanctions and economic trade benefits when trying to pressure non-Western countries to change their anti-sodomy laws. This, in turn, has led legal academics such as Katherine Franke and Stewart Chang to argue that this approach of legalising homosexuality and implementing LGBTQ rights evidences Western-imperialism and neo-colonialism. This paper seeks to contribute to the debate between these polar groups and its main focus is to add to the argument of the latter. This is because whereas there is legal commentary critiquing this aspect of globalisation from the perspective of South East Asian countries and Eastern European countries, there is a gap in the literature coming from African perspectives. Thus the paper will investigate anti-homosexual legislation in Uganda in order to argue that effective legal change to this legislation should come from a change in the normative attitudes of the Ugandan people. It seeks to analyse legal pluralism, legal transplants and legal transfers in order to highlight the importance of normative attitudes in law reform. Thus, the paper will assert that legal reform to anti-homosexual legislation that is resultant of external pressures, as opposed to a change in normative attitudes of the Uganda people, will be detrimental to the development of LGBTQ rights in Uganda.
\end{abstract}

\section{A. INTRODUCTION}

'The world is a global village.' This is a phrase that is commonly used today, as it can be argued that the world at present is more connected than it has ever been. This connectedness that has rapidly increased in the twentieth and the twenty-first century is the result of a highly developed technology realm and processes like globalisation, a method by which the world has sought to function as a single community. ${ }^{1}$ Although globalisation is mostly concerned with the harmonisation of economic communities, ${ }^{2}$ it has also encouraged the development of human rights discourse and the 'recognition of community responsibility extending beyond national borders'. ${ }^{3}$ The pressures towards a convergence of legal culture brought on by globalisation have seen an encouragement in the movement of legal regimes. ${ }^{4}$ Attempts to create a homogenous set of norms and legal orders have resulted in the increased relevance of comparative law.

\footnotetext{
* Patricia Katto (LLB (Hons)), University of Leeds. tona.katto@outlook.com

${ }^{1}$ Edmund Wright, A Dictionary of World History (Oxford University Press 2015).

2 ibid.

${ }^{3}$ Horatia Muir Watt, 'Globalization and Comparative Law' in Mathias Reimann and Reinhard Zimmerman (eds), The Oxford Handbook of Comparative Law (Oxford University Press 2008) 582.

${ }^{4}$ David Nelken, 'Legal Transplants and Beyond: Of Disciplines and Metaphors' in Andrew Harding and Esin Örücü (eds), Comparative Law in the twenty first century (Kluwer Law International, 2002)
} 
The unification of legal rules and social norms, whether it be in the field of economics or in human rights, requires an examination and comparison of different existing legal systems. From this, it is suggested experts in comparative law may draw up a desired set of legal rules which are included in international treaties or transnational agreements. ${ }^{5}$ The states party to these treaties are then obliged to incorporate these new laws into their states. ${ }^{6}$ However, this is arguably an idealistic view of how the international legal regime operates. In many cases, the legal rules that are promoted by international organisations merely universalise the social norms of western countries, as comparative law tends to take a Western bias. ${ }^{7}$ This is not to submit that all human rights that are endorsed by international law today run counter to nonWestern norms and values, as this would be untrue. ${ }^{8}$ However, it is tenable to claim that there is a gap in the literature of both globalisation and comparative law as "it has not addressed the global concerns and the issues raised by "others" from a non-Western perspective. Yet these "others" are growing in importance and need to be studied by lawyers." 9

The wake of globalisation has also witnessed a forced association between LGBTQ rights and economic rights. The examples of Western countries imposing LGBTQ rights on non-Western countries in exchange for economic benefits or sanctions have become more and more prevalent in the twentieth and twenty first century, hence limiting the freedom of countries who are recipients of the migration of some legal regimes. Katherine Franke highlights this in her article titled 'Dating the State', ${ }^{10}$ which argues that gay rights have often been used as a political tool to gain western approval, meaning countries seeking to further their economic standing with the West often change their laws surrounding homosexuality. ${ }^{11}$ She uses the examples of Romania and Poland when they sought to enter the European Union, as the two nations first had to change their anti-sodomy laws before they were able to join the EU. ${ }^{12}$ She highlights the fact that many political parties in the two nations then sought to use anti-sodomy laws as a symbol of nationalism, ${ }^{13}$ thereby indicating that in some cases, the

\footnotetext{
${ }^{5}$ George Mousourakis, 'Legal Transplants and Legal Development: A Jurisprudential and Comparative Law Approach’ (2013) 54 (3) Acta Jurdicia Hungarica 219, 220.

${ }^{6}$ ibid.

${ }^{7}$ Esin Örücü, 'Review Comparative Law in a Global Context: The Legal Systems of Asia and Africa by Werner F Menski' (2003) 66(1) Bulletin of the School of the Oriental and African Studies 157,157 .

${ }^{8}$ Surya P. Subedi, 'The Universality of Human Rights and the UN Human Rights Agenda: The Impact of the Shift of Power to the East and the Resurgence of the BRICS' (2015) 55 (2) Indian Journal of International Law 177, 202.

${ }^{9}$ Örücü (n 7).

${ }^{10}$ Katherine Franke, 'Dating the State: The Moral Hazards of Winning Gay Rights' (2012-2013) 44 Columbia Human Rights Law Review.

11 ibid.

12 ibid 30 .

13 ibid.
} 
imposition of gay rights in this manner, i.e. through the use of economic sanctions or exclusions from trade benefits, may inhibit the development of gay rights in a particular country as a country may begin to regard gay rights as foreign or an import from the West.

Another author that has challenged the imposition of LGBTQ rights on an independent state, namely Singapore, is Stewart Chang. He argues that global gay rights could potentially be regarded as a neo-colonial enterprise as Western countries often use economic threats in order to implement these laws. ${ }^{14} \mathrm{He}$ uses an intersectional analysis to argue that another approach should be taken when endorsing LGBTQ rights in non-Western countries as opposed to "the one-size-fits-all' 15 approach, as this casts negative connotations on gay rights to the Singaporean people.

This paper seeks to add to the ongoing debate between international organisations and Western countries who seek to use donor sanctions and economic trade benefits to invoke LGBTQ rights in non-Western countries which still maintain anti-sodomy laws; and legal academics such as Katherine Franke and Stewart Chang who argue that this approach of implementing gay rights evidences western moral imperialism and neo-colonialism. It is crucial to mention at this juncture that the paper does not in any way whatsoever oppose the promotion of equality laws or pro-LGBTQ laws. The paper recognises that homosexuality should be internationally recognised as a human right, however, it seeks to argue the implementation of LGBTQ rights is more effective when it comes from a change in the normative attitudes of the population of a state rather than external pressures. The issue of whether social norms should effect legal change or whether the legal change should affect social norms resembles 'the chicken and the egg argument'. Nonetheless, this paper seeks to investigate the Anti-Homosexuality Act 2014 in Uganda in order to critique globalisation from an internal perspective. The main focus of this paper is not to add to the top-down versus bottom-up debate amongst legal academics but rather it is to examine the interrelationship of the sociology of law and comparative law. Thus, through an analysis of critical comparative legal theories, it will highlight some of the practical problems faced by and created by globalisation inside the legal world of Uganda. Accordingly, the paper does not intend to comment on the effects of globalisation in its entirety; instead, it will only comment on a small part of the phenomena of globalisation and the law.

\footnotetext{
${ }^{14}$ Stewart Chang, 'The Post-Colonial Problem for Gay Rights' (2014) 32 Boston University International Law Journal 309.

15 ibid.
} 
This paper will be divided into three main sections. The first section seeks to analyse the petition brought forward in the Constitutional Courts of Uganda that aimed to repeal the Anti-Homosexuality Act 2014. The section will identify tensions between three forms of law present in the petition: constitutional law, the Anti-Homosexuality Act and international law. Having highlighted these forms of law, it will then analyse the notion of legal pluralism and use this analysis to argue that the Act was enacted to give legal standing to the societal values surrounding homosexuality, in spite of their contestation under constitutional law and international law. This highlights the great importance of normative rules in society in the change of law. The section seeks to add to the overall argument of the paper which stipulates that a change in normative attitudes towards homosexuality in Uganda is essential to a change in the law.

The second section of the paper will argue that the normative values that drove the AntiHomosexuality Act 2014 can be compared to the normative values surrounding homosexuality in the United Kingdom in the colonial era. It will argue that colonialism saw the implementation of legal and normative rules from the United Kingdom into Uganda and this transplant is one of the reasons for the homophobic attitudes present in Uganda today. The section will analyse the development of anti-gay laws in the United Kingdom up until the point of legalisation of consensual homosexual relationships. This analysis will be used to argue that the change occurred through a change in normative attitudes of the British population without any external pressures and Ugandans should also be afforded the same freedom when it comes to a change in the anti-gay laws in their country. The section will use an analysis of the notion of legal transplants in order to argue that although Uganda's homophobic normative attitudes were introduced through a transplant in legal systems, this was at a time when Uganda was not, in fact, a sovereign country. However, now that Uganda is, in fact, independent, the legal change should not be forced upon it and attempts from the international community to do so may be detrimental to the promotion of LGBTQ rights.

The third section seeks to examine Western responses to the Anti-Homosexuality Act 2014. In consideration of the socio-political factors that influenced the act, the section will argue that the reactions from Western countries only exacerbated homophobic attitudes in Uganda. This section will analyse the development of the rights movement as postulated by Martin Loughlin and will use this model to argue that the development of LGBTQ rights in Uganda would be better endorsed by a legal transfer. It is noteworthy that this section will only focus on the notion of legal transfers as postulated by Gunter Frankenberg and proponents who support his theory. The section will use this theory to claim that the legal transfer of LGBTQ 
rights is dependent on a change of normative attitudes towards homosexuality as these normative attitudes will trigger state actors in Uganda to transfer the laws.

\section{B. PETITION AGAINST THE ACT: THE THREE FORMS OF LAW}

The Anti-Homosexuality Act 2014 in Uganda (hereafter referred to as 'the Act') was heavily contested not only by quite a few Western countries and international organisations but also by LGBTQ rights activists and human rights organisations within Uganda. ${ }^{16}$ The preamble of the Act defined it as 'An Act to prohibit any form of sexual relations between persons of the same sex; prohibit the promotion or recognition of such relations and to provide for other related matters. ${ }^{17}$ The Act clearly depicted homophobic ideology, directly challenging the LGBTQ rights movements endorsed (to varying extents) by some Western countries today. This paper cannot highlight the Act in its entirety thus it will mention s.2 and s.4 of the Act to illustrate the homophobic nature of the Act.

S.2 of the Act made homosexual intercourse and same sex activity between consenting adults punishable with life imprisonment. The provision states:

A person commits the offence of homosexuality if-

he penetrates the anus or mouth of another person of the same sex with his penis or any other sexual contraption;

he or she uses any object or sexual contraption to penetrate or stimulate sexual organ of a person of the same sex;

he or she touches another person with the intention of committing the act of homosexuality

A person who commits an offence under this section shall be liable, on conviction to imprisonment for life. ${ }^{18}$

\section{S.4 states:}

A person who attempts to commit the offence of homosexuality commits a felony and is liable, on conviction, to imprisonment for seven years.

A person who attempts to commit the offence of aggravated homosexuality commits an offense and is liable, on conviction, to imprisonment for life. ${ }^{19}$

\footnotetext{
${ }^{16}$ Stella Nyanzi, 'Dismantling reified African culture through localised homosexualities in Uganda' 15 (8) (2013) Culture, Health \& Sexuality 952,962.

17 The Anti-Homosexuality Act 2014.

18 ibid.

19 ibid.
} 
Although some Western countries applied a lot of pressure on Uganda to prevent the legislation from being enacted, ${ }^{20}$ the parliament still approved the Act and sent it to the President of Uganda, Yoweri Museveni, for ascension. Initially, the president declined to sign the piece of legislation as he insisted that it must be proven that homosexuality was not the product of a 'genetic distortion'. ${ }^{21}$ Although he declared that he viewed homosexuality as socially deviant behaviour, Museveni stalled the implementation of the Act, seemingly because he was wary of punishing members of society for something they could not control. However, upon alleged receipt of scientific evidence proving that homosexuality was 'a choice', ${ }^{22}$ the President decided to sign this piece of legislation. Subsequent to its enactment, the Act was considered null and void by the constitutional courts of Uganda in 2014 as it was deemed to result from a procedural error during its enactment. ${ }^{23}$ In this case, the petitioners brought forward eleven issues; however, the courts only heard and adjudicated on the first issue. The second issue contested the Act for criminalising consensual homosexual intercourse on the grounds that it offended various articles in Uganda's constitution that promoted equality and denounced discrimination. The issue was stated as follows:

That sections 1,2 and 4 of the Anti-Homosexuality Act 2014, in criminalising consensual same-sex/ gender sexual activity among adults in private are in contravention of the right to equality before the law without any discrimination and the right to privacy guaranteed under Articles 2(1) \& (2), 21(1),(2) \& (4) and 27 of the Constitution of the Republic of Uganda respectively; ${ }^{24}$

The subsequent ten issues also challenged different provisions of the Act on the grounds that it violated various articles of the constitution. Moreover, the final issue brought forward by the petitioners challenged the Act on the grounds that it violated various international laws that Uganda was obliged to follow. The issue stated as follows:

That the Anti Homosexuality Act 2014 in criminalizing consensual same sex/gender sexual activity among adults, is in contravention of obligations with regards to the rights

20 Esther Nakkazi, 'Donors Threaten Aid Cuts if Uganda Passes Harsh Anti-gay Bill' (2012) $<$ http://www.theeastafrican.co.ke/news/Donors-threaten-aid-cuts-if-Uganda-passes-harsh-anti-gay-Bill/25581628256-loiy27z/index.html> accessed 6th February 2018

${ }^{21}$ Michael W. Chapman, 'Uganda President to Obama on Gays: 'Respect African Societies and Their Values'What Gays "Do is Terrible"'(2015) <http://www.cnsnews.com/blog/michael-w-chapman/uganda-presidentobama-gays-respect-african-societies-and-their-values-what $>$ accessed 20th February 2017

22 ibid.

23 David Smith, 'Uganda anti-gay law declared 'null and void' by constitutional court' (2014) https://www.theguardian.com/world/2014/aug/01/uganda-anti-gay-law-null-and-void $>$ accessed $16^{\text {th }}$ January 2017

${ }^{24}$ Prof Oloka-Onyango \& others v Attorney General Constitutional Petition No. 08 of 2014 (Constitutional Court of Uganda) 
guaranteed under international Human Rights instruments ratified or acceded by Uganda, including the African Charter on Human and People's Rights, the Protocol to the African Charter on Human and Peoples' Rights, Rights on the Rights of Women in African, the UN Covenant on Civil and Political rights; and the UN Covenant on Economic, social and Cultural rights; and in contravention of Objectives XIV, XXXVIII(i) (b) of the National Objectives and Directive Principles of State Policy, Articles 2(1) \&(2), 8A, 2045 and 287 of the Constitution; ${ }^{25}$

The issues presented by the petitioners evidence a plurality of the legal regimes in Uganda. There are clearly three states of law present: the constitution, the Anti-Homosexuality Act 2014 and international law. This raises the question of why Uganda would enact this legislation even though it would greatly conflict with existing constitutional laws in Uganda as well as international laws. It can be argued that this was because the Ugandan government sought to give legal standing to very ubiquitous normative attitudes surrounding homosexuality in Uganda, ${ }^{26}$ which highlights the importance of normative attitudes in society.

\section{Legal Pluralism: The Act versus the State versus the West}

'Law is a complex thing... for law among other things is both a pragmatic intervention and a philosophical-political narrative. ${ }^{27}$ Therefore, there are many different formations to what is known conventionally as the law'. There may be purely technical laws, such as the laws that dictate that Americans drive on the right and the British drive on the left. There is arguably no moral reason or cultural value to explain why one should drive on the side of the road in which they do, these laws are simply there to create order in society. However, there are also laws that are reflective of morality. The relationship between law and morality has been a topic of study for not only lawyers but also philosophers. Jan Klabbers writes 'the history of jurisprudence is replete with the debate concerning, in particular, the relationship between law and morality. ${ }^{28}$ Nonetheless, this is not the relationship that this paper seeks to explore. This article seeks to analyse the laws that are a reflection of the societal norms and values around them. It is not to argue that these types of law are mutually exclusive. There may be existing laws that not only reflect a perceived moral rule but a normative value as well or, as in the case

\footnotetext{
25 ibid.

${ }^{26}$ Stella Nyanzi \& Andrew Karamagi, 'The social-political dynamics of the anti-homosexuality legislation in Uganda' (2015) 29 (1) Agenda

${ }^{27}$ Ralph Sandland, 'Running to Stand Still' (2009) 18 Social \& Legal Studies 253,253

28 Jan Klabbers and Touko Piiparinen, 'Normative Pluralism: An Exploration' in Jan Klabbers and Touko Piiparinen (eds), Normative Pluralism and International Law: Exploring Global Governance (Cambridge University Press 2013) 20.
} 
of the Act, it may reflect a normative value but violate a perceived moral rule. However, this paper is concerned with the relationship between the law and normative order.

Klabbers defines normative orders as 'a set of related commands, injunctions, "do's and don'ts" that stem from the same source or a multitude of similar sources'. ${ }^{29}$ With this definition, the law in its generality becomes a normative order as most laws stem from statutory provisions or case law. ${ }^{30}$ Thus the law becomes one of the many normative orders posited in society, ${ }^{31}$ which also include religion and education, to give two examples. Although the law is a normative order enforced by the state, this is not to say that it is completely separate from other normative orders. Eugen Ehrlich asserts that the law and societal norms and interactions are not mutually exclusive. Therefore, although there is a black letter law, this is not separate from the customs and norms of society. ${ }^{32}$ In his analysis of Ehrlich, Emmanuel Melissaris writes 'Ehrlich's analysis is valuable in that it brings to the surface social formations with selfregulating mechanisms which are independent from the law of the state and that this "living law", being much more direct is more binding for the people. ${ }^{33}$ For Ehrlich and proponents of his theory, the law cannot exist in isolation from societal norms and customs and because societal norms and customs are so pervasive in society they tend to not only influence the law but at times be more influential than it.

The existence of many normative orders inevitably brings about contestation, and accordingly, there may be instances where there are different normative orders claiming authority over each other. This tension that is caused by the existence of a plurality in law or a plurality in normative orders in society is what is known as normative/legal pluralism. ${ }^{34}$ For ease of reference, this paper will continue to refer to the theory as legal pluralism. The broadness and complexity of the law makes legal pluralism a 'meta-theory'35 or a 'metajurisprudence' ${ }^{36}$ This aspect of legal pluralism is one that is highlighted by many scholars in the field. Brian Tamanaha writes 'there is plurality in legal pluralisms', ${ }^{37}$ whilst Jennifer Hendry asserts 'The potential scope of the concept of legal pluralism lend it a malleability that

\footnotetext{
29 ibid 21.

30 ibid.

${ }^{31}$ Pierre Legrand, "Foreign Law: Understanding Understanding" (2011) 6 Journal of Comparative Law 67,70.

32 Emmanuel Melissaris, 'The More the Merrier? A New Take on Legal Pluralism' (2004) Social \& Legal Studies $58,59$.

33 ibid 60.

34 William Twinning, 'Globalization and Comparative Law' (1999) 6 Maastricht Journal of European and Comparative Law 217, 226.

${ }^{35}$ Melissaris (n 32).

${ }^{36}$ ibid.

37 Brian Tamanaha, 'Understanding Legal Pluralism: Past to Present, Local to Global' (2008) 30 Sydney Law Review 375, 387.
} 
operates as a double-edged sword: on the one hand it is flexible enough to be discussed from many different perspectives, while on the other it appears to lack any real defining contours, other than being premised on contestability. ${ }^{38}$ As the case study of this paper is Uganda and its Anti-Homosexuality Act 2014, the plurality of legal pluralism has proven beneficial as the paper will be able to analyse legal pluralism through an internal and external perspective. The paper will use the former in order to argue that the enactment of the Act was an attempt of the post-colonial State to give legal standing to normative attitudes already existing in Uganda in spite of its conflict with the constitutional rights to privacy of person, home and other property. The paper also seeks to analyse legal pluralism from an external perspective. The paper will argue that, as international law is intrinsically pluralistic in its nature, there is a fundamental contestation in international law, and that in most cases Western values are upheld over values of non-Western countries. Therefore, in cases where there is tension between the international and national laws, states often seek to enforce laws that represent prevalent social attitudes above those that do not.

\section{The Act Versus International Law: International Legal Pluralism}

Andre Nollkaemper, an international law academic, identifies two types of international legal pluralism that offer a clear understanding of the relationship between international laws and national laws. However, he makes it clear that although there is empirical data to support his two notions of international legal pluralism, they are not factual descriptions but rather distinct paradigms of the relationship between international law and national law. ${ }^{39}$ An analysis of his work will offer a plausible explanation as to why the Ugandan parliament decided to enact the Act despite its incompatibility with international law.

Firstly, Nollkaemper highlights an 'internal' legal pluralism which he describes as the intrinsically pluralistic nature of international legal orders. Brian Tamanaha also makes this point about international law when he writes 'if one envisions matters from the standpoint of a global or transnational legal system, that legal system is immediately pluralistic because it contains and interacts with a multitude of coexisting, competing and overlapping legal systems at many levels'. ${ }^{40}$ International legal pluralism is a factor that greatly affects the goal of international law which, to a large extent, is to harmonise certain elements of normative orders

\footnotetext{
${ }^{38}$ Jennifer Hendry, 'Legal Pluralism and Normative Transfer' in Gunter Frankenberg (eds), Order from Transfer: Comparative Constitutional Design \& Legal Culture (Cheltenham, Edward Elgar, 2013) 158.

${ }^{39}$ Andre Nollkaemper, 'Inside or Out: Two Types of International Legal Pluralism' in Jan Klabbers and Touko Piiparinen (eds), Normative Pluralism and International Law: Exploring Global Governance (Cambridge University Press, 2013).

40 Tamanaha (n 37) 375, 387.
} 
in the world, especially in the area of human rights. ${ }^{41}$ However, as it has to take into account different legal and normative orders it often prioritises the dominant societal values of some countries over others. This seems to be the case with homosexuality.

In Western European and North American countries homosexuality has only recently been regarded as a human right. This is evidenced by case law such as Identoba and Others $\mathrm{v}$ Georgia $^{42}$ and M.C and A.C v Romania ${ }^{43}$ where the European Court of Human Rights deemed that Georgia and Romania were in breach of various articles of the European Convention for Human Rights in their discrimination against homosexual couples. This approach can be directly contrasted with post-colonial countries like Uganda and Singapore who continue to criminalise homosexuality. By advocating pro-LGBTQ rights, international organisations like the United Nations arguably champion predominant Western opinions of what should be considered a human right. The theory of 'internal' international legal pluralism as postulated by Nollkaemper argues that this legal ordering is necessary in international law and in order for international law to be effective it is inevitable that some normative orders and some legal orders will be upheld over others. Nonetheless, in order for international law to be effective nations must uphold this international law and grant it supremacy.

However, this is not always the case: as the enactment of the Act clearly illustrates, in some cases the contestation between international law and national legal orders leads to a prioritisation of national orders as opposed to international legal order. This is what Nollkaemper describes as 'external' international legal pluralism. ${ }^{44}$ External international legal pluralism recognises that it is the national sphere that has the overall power as it dictates how international obligations are implemented at the national level. In the case of the Act's enactment, it can be argued that Uganda used this power to uphold its own normative orders above international law. This clearly portrays the strength of social norms and values in the legal sphere as they were regarded as much more important than international law and hence were given legal standing. Therefore, it can be argued that in order to change the existing homophobic laws in Uganda as well as ensure the recognition of LGBTQ rights as human rights, a change in the normative attitudes of the Ugandan people will prove more effective than domestic cases relying on international law.

\footnotetext{
${ }^{41}$ Andre Nollkaemper, 'Inside or Out: Two Types of International Legal Pluralism' in Jan Klabbers and Touko Piiparinen (eds), Normative Pluralism and International Law: Exploring Global Governance (Cambridge University Press, 2013)

${ }^{42}$ Identoba and Others v Georgia (2015) 4 ECHR 157

${ }^{43}$ M.C and A.C v Romania (2016) 4 ECHR 126

${ }^{44}$ Nollkaemper (n 41).
} 


\section{The Act Versus the Constitution: Western Nomos and Ugandan Narrative}

Nonetheless, as the paper mentioned above, not only was there a contestation between international law and the Act - there was also a contestation between the constitution and the Act. This paper will use Robert Cover's model of 'Imperial law' in order to offer an explanation of the tension between the constitution of Uganda and the Act. Although Cover was not strictly speaking as a legal pluralist, ${ }^{45}$ his analysis of pluralities in law in his description of imperial Law is valuable to this paper. In his article 'Foreword: Nomos and the Narrative,' Cover presents the notion of Narrative which he interprets as the discourse situated in society, the way in which different groups in society interpret and perceive different values. ${ }^{46}$ For example, different members of society will have different opinions on homosexuality. Some may actively advocate for it to be recognised as a human right, some may view it as an act that should be criminalised whilst some may be indifferent and not mind whether it is criminalised or not. Cover explains that consequently, some interpretations are regarded as more valuable than others and are thus given legal standing or legal meaning by the State; once this happens they transform from Narrative to Nomos. ${ }^{47}$ Cover defines this process as 'jurisgenesis ${ }^{48}$ and explains that the state is able to use violence and force in order to elevate some values and interpretations over others. However, the violence and force that Cover refers to is not violence and force in their conventional meanings. The state does not generally threaten to physically harm those that do not comply with what they have deemed Nomos (albeit that in some instances the state does). However, the state uses institutions in society to gain commitment from individuals to adhere to the values they have set out. He writes that 'In this model, norms are universal and enforced by institutions. They need not be taught at all as long as they are effective. Discourse is premised on objectivity - upon that which is external to the discourse itself.' $^{49}$

Colonialism saw the infliction of British Laws and customs on the people of Uganda. One of these laws was the anti-sodomy law in the penal code of Uganda. The law brought about homophobic ideology and thus colonialism saw the imposition of both homophobic Nomos and Narrative on the Ugandan people. However, following the colonial era, homophobic discourse in Uganda became more and more prevalent and aggressive. This is arguably because

\footnotetext{
${ }^{45}$ Melissaris (n 32).

46 ibid 4, 10.

47 ibid.

48 ibid.

49 ibid.
} 
of the increase in conservative religious discourse in $\operatorname{Uganda}^{50}$, as well as the use of disgust: ${ }^{51}$ anti-gay political leaders and normative actors, such as pastors, in Uganda, have associated homosexuality with disgusting images such as eating feces and the spread of disease. ${ }^{52}$ Given that about $82.4 \%$ of the Ugandan population is Christian, ${ }^{53}$ it is likely that if religious leaders associate homosexuality with disgusting images it will in turn, lead to the decrease in levels of tolerance for homosexuality in the country. Additionally, King Mwanga, the King who ordered the killings of the Uganda Martyrs, was labelled a homosexual. ${ }^{54}$ The Uganda Martyrs are celebrated in Uganda every June $3^{\text {rd }}$. Therefore, by making King Mwanga (the villain in the event) the spokesperson for homosexuality, the anti-gay supporters aggravated homophobic attitudes in Uganda, ${ }^{55}$ thereby causing an increased homophobic Narrative.

This heightened homophobic Narrative was evidenced in the documentary 'The World's Worst Place to Be Gay'. In this documentary, the presenter Scott Mills shows the viewers seven informal interviews with Ugandan people in the streets of Kampala where he questioned them on what should be done to people who are discovered to be homosexual. All of the interviewees declared that they should be imprisoned, whilst the majority of them said they should be imprisoned or killed. ${ }^{56}$ The increased homophobic Narrative arguably carried a discrepancy between the Narrative surrounding the anti-sodomy laws of the colonial era in that it was more aggressive. Consequently, it is plausible that the enactment of the Act was a way for the State of Uganda to give legal standing to this increased homophobic ideology; a way to convert the new Narrative into a new Nomos. However, it is important to acknowledge that this is a two-way process because in creating this new Nomos the state actors may also play a role in encouraging the narrative.

Additionally, the influence of prevalent social norms in the enactment of the Act was also reflected in an interview between the President of Uganda and CNN. In the interview he said 'I am acting on behalf of the society. It is not just the state; it is the society. And that's why I would like to advise the Europeans and the Western group that this is one area which

\footnotetext{
${ }^{50}$ Nyanzi (n 16) 952,962.

${ }^{51}$ Michael Ashworth, 'Affective Governmentality: Governing Through Disgust in Uganda' (2016) Social \& Legal Studies 1,12 .

52 ibid.

53 Yasiin Mugerwa, "Uganda: Catholics, Anglicans decline as Muslims and Pentecostals rise" (2016) $<$ http://allafrica.com/stories/201603280284.html> accessed 6 February 2018

${ }^{54}$ Rahul Rao, 'Re-Membering Mwanga: Same-Sex Intimacy, Memory and Belonging in Post-colonial Uganda' (2014) 9 Journal of Eastern African Studies 1, 9. 
should be a no-go area. ${ }^{57}$ It is clear from this statement that Museveni regarded the Act as a representation of the normative values of Uganda. Furthermore, he regarded the protection of these societal values as so important that they should be given legal standing in an act of their own. However, it is important to recognise that by giving these normative values legal standing, the President was encouraging them in society. The Act signifies the paradigm of Imperial Law; it was given legal standing through the force of the parliament and demands the commitment of the Ugandan people. This clearly depicts the importance of normative values in a society: they shape and change the law and thus should be taken into consideration when trying to reform the law.

The strength of social norms and values in the making of laws in Uganda is also demonstrated in the way by which the Act was given legal standing despite the fact that it violates the constitutional right to privacy of person, home and other property. ${ }^{58}$ The Constitution of Uganda represents the alleged supreme laws of the state. ${ }^{59}$ It represents a set of values that Uganda is supposed to uphold above all other values and article 2(2) of the constitution goes on to mention that in the event of any inconsistencies between any other legislation and the Constitution, the Constitution shall prevail. ${ }^{60}$ The Act clearly infringes on the right to privacy of person, home and other property as it allows the government to police the home life of the public to ensure that they are not engaging in homosexual acts. As such, if the Constitution was in fact regarded as superior law then the Parliament would not have given the Act legal standing. However, 'It is essential to recognise that the priority officially accorded to state law in these situations says nothing about the power of law in social life... since the bulk of state legal norms were transplanted from elsewhere they almost inevitably did not match the norms that prevailed in social life' ${ }^{61}$ It is notable that the first draft of the constitution of Uganda, the draft that introduced the right to privacy of home life was heavily influenced by the British, ${ }^{62}$ therefore in the context of the quote above by Tamanaha it would become secondary to the norms that prevail in Uganda's social life as it was a state legal norm transplanted from elsewhere.

\footnotetext{
${ }^{57}$ M. W. Chapman, 'Uganda President to Obama on Gays: 'Respect African Societies and Their Values'- What Gays "Do is Terrible"” (2015) < https://www.cnsnews.com/blog/michael-w-chapman/uganda-president-obamagays-respect-african-societies-and-their-values-what $>$ accessed $20^{\text {th }}$ February 2017

58 Art 27, Constitution of Uganda 1995

${ }^{59}$ Art. 2, Constitution of Uganda 1995.

${ }^{60}$ Constitution of Uganda 1995.

${ }^{61}$ Brian Tamanaha, 'Understanding Legal Pluralism: Past to Present, Local to Global' (2008) 30 Sydney Law Review 375, 389.

${ }^{62}$ 'Constitutional history of Uganda' <http://www.constitutionnet.org/country/constitutional-history-uganda > accessed 28 February 2017.
} 
Additionally, it is tenable to postulate that the Ugandan government was able to justify the infringement on the public's right to privacy by the Act with the argument that it was in the interest of public health. ${ }^{63}$ This justification was made in spite of the fact that various public health advocates warned about the health risks of enacting the Act. ${ }^{64}$ As the paper previously mentioned, the Narrative surrounding homosexuality in Uganda portrays homosexuality as a choice. Furthermore, as the paper pointed out, in the normative realm, the use of disgust associates homosexuality with the spread of disease and other such arguments. ${ }^{65}$ Accordingly, the dominant narrative surrounding homosexuality does not portray it as a human right that should be protected by the constitutional right to privacy but rather it describes it as socially deviant behaviour that is capable of spreading disease and thus should be punished through criminal law. Hence in such an instance, the black letter law promoting rights to privacy of home life would not warrant the same protection as that of the alleged interest for public health. This illustrates the strength of prevalent normative values in the process of law making, as the Parliament was willing to uphold the normative opinions of homosexuality that associate it with disgusting images over the Constitution and the opinions of public health advocates.

Consequently, it is clear from this section that legal pluralism in Uganda poses a problem for globalisation of LGBTQ rights. The existence of a dominant homophobic normative order will surely make it difficult for external pressures to implement change in the area of LGBTQ rights as contestation of the constitution itself was not enough to deter state actors from giving legal standing to these homophobic attitudes. This gives weight to the argument that the change must come internally. Nevertheless, the fact that the Act was considered null and void, may be considered a step towards implementing LGBTQ rights in Uganda, even though the ruling was made on the procedural error and was not based on the substantive content. However, this is a very small step because Uganda continues to have antisodomy laws notwithstanding the Act, as the following section will highlight.

\section{A. COLONIAL AMNESIA IN A GLOBALISING WORLD: THE DOWNSIDE TO LEGAL TRANSPLANTS}

\footnotetext{
63،President Museveni signs Anti-gay bill into law' (2014) $<$ https://www.newvision.co.ug/new_vision/news/1338049/president-museveni-signs-anti-gay-law> accessed 17 February 2018

64 Christina Nunez, 'Public Health Advocates Celebrate Annulment of Uganda's Anti-Gay Law' $<$ https://www.globalcitizen.org/en/content/public-health-advocates-celebrate-annulment-of-uga/ $>$ accessed 17 th February 2018

${ }^{65}$ Ashworth (n 51).
} 
Prior to the ruling of the Ugandan Constitutional courts to make the Act illegal, s.145 of the Penal Code Act 1950 made homosexual intercourse a criminal offence. The provision, which is still in force, states:

Any person who

Has carnal knowledge of any person against the order of nature

Has carnal knowledge of an animal; or

Permits a male person to have carnal knowledge of him or her against the order of nature,

Commits an offence and is liable to imprisonment for life; $; 6$

Furthermore s.148 prohibited same sex activity through the offence of gross indecency. The provision states:

Any person who, whether in public or in private, commits any act of gross indecency with another person or procures another person to commit any act of gross indecency with him or her or attempts to procure the commission of any such act by any person with himself or herself or with another person, whether in public or in private, commits an offence and is liable to imprisonment for seven years; ${ }^{67}$

Therefore, although the Act attracted a lot of controversy, Uganda already had and continues to have anti-sodomy and anti-gay laws on its books that greatly conflict with the LGBTQ rights advocated by some Western countries and international organisations today. However, this contrast between legal and social attitudes towards homosexuality in Uganda and Western Countries, more specifically the UK, was not always present. As mentioned earlier in this paper, the current provision that makes homosexual intercourse illegal in Uganda was enacted during Uganda's colonial era. Jürgen Osterhamuel defines colonialism as 'a relationship of domination between an indigenous (or forcibly imported) majority and a minority of foreign invaders. The fundamental decisions affecting the lives of the colonized people are made and implemented by the colonial rulers... ${ }^{68}$ Hence the colonial era in Uganda saw the imposition of British norms, customs and legal rules on the Ugandan people. Furthermore, Gardner Thompson also writes about the British policies in Uganda during the colonial era, stating that '[they] were enacted to achieve their own metropolitan goals. ${ }^{69}$ Therefore, any laws that were passed in the colonial era were reflective of British laws and social norms at the time; this

\footnotetext{
${ }^{66}$ s 145 Penal Code Act 1950.

${ }^{67}$ s 148 Penal Code Act 1950.

${ }^{68}$ Jürgen Osterhammel, Colonialism: A Theoretical Overview (Markus Weiner Publishers 2005).

${ }^{69}$ Gardner Thompson, Governing Uganda: British Colonial Rule and Its Legacy (Fountain Publishers 2003$) 9$.
} 
correspondence was evident in the homosexuality laws of the two states prior to Uganda's independence.

The laws surrounding homosexuality in the UK during the colonial era were provided by the offence of gross indecency in s.11 of the Criminal Amendment Act $1885 .{ }^{70}$ The provision is completely identical to the offence of gross indecency in s.148 of the Penal Code Act 1950 in Uganda - the only difference is contained in the sentencing. Whereas s. 148 of the Penal Code Act sentences offenders to seven years, s.11 of the Criminal Amendment Act only sentenced them to two years. Additionally, s.61 of the Offences Against the Persons Act 1861 made what it referred to as the 'abominable crime of buggery' (anal intercourse) punishable by life imprisonment. ${ }^{71}$ The offences of buggery and gross indecency were later re-codified by s.12 and s.13 of the Sexual Offences Act 1957 (SOA) respectively. The homophobic ideology behind these two offences was clearly foisted upon Uganda during the colonial era in the form of s. 145 and s.148 of the Penal Code Act 1950. However, unlike Uganda, the UK saw the repeal of these provisions with the enactment of the Sexual Offences Act 1967. This act provided for the partial legalisation of homosexual intercourse in the UK as s. 60 made it lawful for consenting homosexuals above the age of twenty-one to engage in intercourse. This was the first step in the promotion of gay rights in the UK, hence this section will examine the change in societal attitudes that stimulated this change in the law.

It took centuries for the laws surrounding homosexuality to change in the UK and this change was caused internally. It was prompted by a British government study popularly known as 'the Wolfenden Report'. ${ }^{72}$ The Wolfenden Report was plausibly pressured by an increase in the number of prosecutions surrounding homosexuality in the 1950's. 'In 1952, there had been 670 prosecutions in England for sodomy; 3082 prosecutions for attempted sodomy or indecent assault; and 1686 for gross indecency. ${ }^{73}$ These cases included high profile cases and it is argued that this is what sparked the attention and intrigue of the public on the issue of homosexuality and hence led to the parliament calling for an investigation into the issue. ${ }^{74}$ Claude J Summers writes about the report, stating that 'The rationale for the committee's recommendation to decriminalise homosexuality... included a number of heart-wrenching case histories culled from police reports and court cases. The committee condemned homosexuality

\footnotetext{
$70<$ https://archive.org/details/criminallawamen00bodkgoog $>$ accessed 17 January 2017.

${ }^{71}$ Offences Against the Persons Act 1861.

${ }^{72}$ GLBTQ Claude J. Summers, "The Wolfden Report" http://www.glbtqarchive.com/ssh/wolfenden_report_S.pdf> accessed 16 January 2017.

73 ibid.

74 ibid.
} 
as immoral and destructive but concluded that outlawing homosexuality impinged on civil liberties. ${ }^{75} \mathrm{He}$ then goes on to say that the report also concluded that homosexuality was not a mental illness This idea of homosexuality being a mental disease that was present in the United Kingdom can be directly compared to the rhetoric present in Uganda that led President Museveni to investigate whether homosexuality was a 'genetic distortion'. Thus, it can be argued that the societal attitudes present in the United Kingdom in the colonial period are somewhat similar to the ones present in Uganda today.

The testimonies of some of the people who suffered under the law were poignant and numerous enough to cause a small change to the way society viewed homosexuality and subsequently this normative change was impactful enough to develop the law. The change in law was then able to assist in the further development of normative attitudes to homosexuality which ultimately led to its protection under the rights based model.

Case law proved instrumental in the change of societal attitudes towards homosexuality in the UK. The vast amount of criminal cases that arose from the anti-sodomy and gross indecency laws in the UK can be contrasted with the case law arising from the Act in Uganda. During its legal tenure, there were no convictions for offences under the Act. It is feasible that this is because the Act's legality was contested shortly after its enactment and so it was difficult for any cases to be brought forward in court whilst there was uncertainty. However, the first homosexual couple to be tried in Ugandan courts under the current anti-sodomy laws was in 2014. This was sixty-four years after the law was first introduced into Uganda. It is possible to speculate on a number of factors that may have influenced the time-lapse between the enactment of the law and the first homosexual trial, such as: political instability in Uganda from 1960 to 1986; a lack of and/or inadequate policing; and / or the Ugandan police using the anti-sodomy laws to blackmail same-sex couples as opposed to charging them. Nonetheless, the lack of case law illustrating how people had suffered under the anti-sodomy laws already in Uganda would perhaps constrain a change in societal attitudes towards homosexuality as it reduces the evidence of how homosexuals suffer at the hand of the laws.

Uganda v. Mukisa Kim and Mukasa Jackson ${ }^{76}$ was the first LGBTQ case to be tried in the courts of Uganda. The case involved a homosexual man and a transgender woman who were accused of having sexual intercourse that offended s.145(a) and s.145(c) of the Penal

\footnotetext{
${ }^{75}$ Summers (n 72).

${ }^{76}$ Criminal case no. 0085 of 2014
} 
Code Act 1950. The case was later dismissed due to a lack of evidence from the prosecution. ${ }^{77}$ Since then, there have been no records of any homosexual couples being sentenced in Ugandan courts under s.145 of the Penal Code Act. The anti-sodomy laws in the United Kingdom saw multitudes of homosexuals sentenced to life imprisonment; however, this is not the case in Uganda. The United Kingdom was able was able to identify the problem with adjudicating on sexual morality as they witnessed a large number of their population suffering as a result of it. The development of the law happened organically. It is tenable to assert that homosexuals in Uganda should not have to suffer for a change in the law to be provoked; rather Uganda should instead learn from what happened to homosexuals in the United Kingdom up until 1967 and use this history to re-shape their own laws on homosexuality now. This is part of the narrative behind pressures from Western countries and international organisations to change the antisodomy laws and the former pressures to repeal the Act. They suggest a movement of the rights-based model protecting homosexuality in Western countries into Uganda. This movement would be irrespective of the prevalent societal norms of the Ugandan people but rather would take into account the way in which LGBTQ rights operate in western countries. Thus it suggests a legal transplant of said rights. However, an analysis of legal transplants will demonstrate why the societal norms of the Ugandan people must be changed before there is a change in the laws surrounding homosexuality.

The paper does not argue that case law is essential in the recognition of the inherently immoral nature of the anti-gay laws. Therefore, it is not to say that the only way in which the law in Uganda may develop is if there are more cases of homosexual couples suffering due to the anti-gay laws. The section highlights the role played by case law in the change of the homophobic rhetoric in the UK, nonetheless, there are other ways to influence a change in the homophobic normative attitudes in Uganda, for example, awareness campaigns to challenge the politics of disgust. ${ }^{78}$

Instead, this section argues that if there is a forced legal transplant of LGBTQ rights into Uganda, a transplant based purely on examples of case law from Western countries, it is reasonable to suggest that this is reminiscent of colonialism. This is because once again the legal system in Uganda would be moulded by legal actors and legal events outside the country. 'Colonialism is not just any relationship between master and servant but one in which an entire

\footnotetext{
${ }^{77}$ HRAPF, 'Court Dismisses Charges of Unnatural Offences Against Two men' (2014) <http://hrapf.org/courtdismisses-charges-of-unnatural-offences-against-two-men/> accessed 18 January 2017.

${ }^{78}$ John C Mubangizi, 'Protecting the Right to Freedom of Sexual Orientation: What can Uganda Learn from South Africa?’ (2011) 22 Stellenbosch Review 330,349
} 
society is robbed of its historical line of development, externally manipulated and transformed according to the needs and interests of the colonial rulers'. ${ }^{79}$ Consequently, by the United Kingdom or other Western countries seeking to force a legal change in the Anti-homosexual laws in Uganda through a transplant of their own rights-based model, they deprive Uganda of the historical development that they themselves were afforded, thus reflecting tenets of neocolonialism. Considering this argument, the article will now go on to argue why a legal transplant of LGBTQ rights would not be suitable in Uganda.

\section{The Possibility of Legal Transplants in the Post-Colonial Era}

The objective of this paper in its discussion of legal transplants is not to deconstruct the theory of legal transplants or to contend the theory outright. Rather, the essay wishes to assert that the relationship between law and society is more nuanced and complex than the creator of the theory, Alan Watson, ${ }^{80}$ postulates. The theory of legal transplants contests the mirror-theory. ${ }^{81}$ The mirror theory is one that argues that a change in any given legal rule or the law in general is a response to an external force. So a law may be influenced by the economy, by societal norms or by history. Therefore, a change in that law depends on a change in its influencing factor. ${ }^{82}$ As this essay seeks to argue that changes in the law surrounding homosexuality are dependent on a change in societal attitudes towards homosexuality, it easy to argue that this paper supports this mirror theory. However, this would be a misconception of the argument of the paper because it is reasonable to assert that the mirror theory also simplifies the relationship between law and society in the same way that the proponents of Watson's legal transplants do. There is a difference between recognising the importance of normative values in the change of particular laws and an assertion that this is the only way the law may develop. The paper seeks to do the former.

Watson in his theory of legal transplants argues that a change in the law is completely separate from any other societal or subjective changes, whether these changes be in the school of economics or of history or even in cultural change. ${ }^{83} \mathrm{He}$ argues that the law is autonomous, therefore the law can seamlessly be transferred from one legal regime to another even though

\footnotetext{
${ }^{79}$ Jürgen Osterhamuel, Colonialism: A Theoretical Overview (Markus Weiner 2005)

${ }^{80}$ Alan Watson, 'The Birth of Legal Transplants' (2012-2013) 41 Georgia Journal of International \& Comparative Law 605,605

${ }^{81}$ William Ewald, 'Comparative Jurisprudence (II): The Logic of Legal Transplants' (1995) 43 American Journal of Comparative Law 489, 491

82 ibid 489, 493.

83 Pierre Legrand, 'The Impossibility of Legal Transplants' (1997) 4 Maastricht Journal of European \& Comparative Law 111, 112
} 
there are cultural differences between the two regimes. ${ }^{84}$ He argues that this claim is supported by examples in history where Roman Law has been transplanted to various Western European countries in the area of private law. ${ }^{85}$ Hence, the fact that these Roman Law principles still exist in private law in Western countries today contributes to the longevity of the argument of legal transplants. Thus within the context of the Act and the anti-sodomy laws in Uganda, exponents of the legal transplants theory would argue that notwithstanding cultural differences, a change in the law surrounding homosexuality would be possible if there were a transplant of the Western rights-based model surrounding homosexuality into Uganda.

In his critique of legal transplants, William Ewald distinguishes between two paradigms of the interrelations of law and society presented by Watson in his work. He first draws upon a 'stronger Watson'. He uses this phrase to describe the generalised version of legal transplants that have been mentioned by the paper, i.e. that a change in law is not dependant on social interactions, but rather on transplantation of laws from foreign legal regimes. ${ }^{86}$ This is a very simplistic version of the stronger Watson theory, but encapsulates the point Ewald was contending, which is that such the stronger Watson is detrimental to the whole theory of legal transplants, as it is generic and does not account for the complex nature of the law. ${ }^{87}$

Alternatively, the other Watson, the 'weaker Watson', argues that there are some laws that are peculiar to certain societies, meaning legal transplants may be preferred in a change to specific types of law as these types of law are not dependant on societal engagement or interaction. He argues that this version of legal transplant is better supported by empirical evidence throughout the world. He writes

For a theory that says there is no significant relationship between law and politics (or society or economics or religion or whatever) leaves us with nothing to say. Whereas, the weaker version lays stress on the complexity of the phenomena, pointing out that the relationship between law and society is neither non-existent nor a simple mirroring but a subtle and intricate relationship that must be studied case by case. ${ }^{88}$

The Weaker Watson's theory finds support amongst legal academics such as Otto KahnFreund, who also holds the view that some areas of law are transplantable whilst others are less

\footnotetext{
${ }^{84}$ George Mousourakis, 'How Comparative Law Can Contribute to the Development of a General Theory on Legal Evolution' (2007-2008) 14 Tilburg Law Review 272,286.

${ }^{85}$ Alan Watson, 'The Birth of Legal Transplants' (2012-2013) 41 Georgia Journal International \& Comparative Law 605, 605.

${ }^{86}$ Ewald (n 81).

87 ibid.

${ }^{88}$ ibid 489,504.
} 
so. ${ }^{89}$ Proponents of Watson's weaker theory therefore, differentiate between 'mechanical' transplants and 'organic' transplants. ${ }^{90}$ The former involve technical legal rules and the latter involve institutional structures and processes, meaning the former are more suitable for transplantation and the latter require the "careful selection and adaptation of the relevant norms for them to flourish in the new legal environments'. ${ }^{91}$ It is tenable to assert that the transfer of LGBTQ rights into Uganda would require an 'organic transplant', if any, because as section one demonstrated, the social norms behind the anti-gay laws carry an immense amount of authority.

However, perhaps a more important question is not whether a law is transplantable but rather how the law is being transplanted. ${ }^{92}$ Take a scenario of a parent-child relationship where a child is under the care of the parent and the parent decides the child is in need of a medical transplant. The parent may give consent to the doctor to proceed with this medical transplant despite the opinions of the child. However, imagine a second scenario, where the child is now an adult and the parent deems that he/she should undergo another medical transplant. However, now that the child is an adult, the child decides they would not wish to have this medical transplant. It would arguably be wrong for the parent in this situation to try and coerce the child into getting the transplant through threats. It can be argued the first scenario represents legal transplants during colonialism, as the United Kingdom did not have to take into account the societal opinions of the Ugandan people when evoking legal change through a transplant of their legal rules. This is because the Ugandan people were under the rule of the British or part of the British empire. The British were able to simply transplant their rules from one place to another. The objective of using this scenario is not to compare colonialism to a parent-child relationship or to cause offence by doing so but rather the reason for these two scenarios is to illustrate that even if a legal transplant were to take place, the transplant must come voluntarily from the lawmakers of Uganda, thus the societal attitudes of the Ugandan people would still be crucial because it should be these attitudes driving the pressure force in reception of the transplant. This would therefore need a change in the prevalent social attitudes which are currently homophobic. ${ }^{93}$

\footnotetext{
${ }^{89}$ Otto Khan-Freund, 'On Uses and Misuses of Comparative Law' (1974) 37 Modern Law Review 1,21

${ }^{90}$ John Gillespie, 'Towards a discursive analysis of Legal Transfers into Developing East Asia' (2007-2008) 40 New York University Journal of International Law \& Politics 657, 664.

${ }^{91}$ ibid.

92 Esin Örücü, 'Law as Transposition' (2002) 51(2) International and Comparative Law 205, 208.

93 Nyanzi (n 16).
} 
Moreover, even though there is room for the argument that legal transplants are possible, i.e. a law may be moved from one environment to the other without concern about the legal recipient's normative environment, it cannot certainly be submitted that the law that is being transplanted would have an identical effect on its recipient environment. ${ }^{94}$ This is an argument made by Gunther Teubner who referred to legal transplants as 'legal irritants' ${ }^{95} \mathrm{He}$ points out that a transplant does not act in a vacuum. He argues that even if a law was to be transplanted it would react with the host environment it is transplanted into; the process would therefore not only reshape the legal system of the host environment but also the law that is being transferred itself. ${ }^{96}$ This is evidenced by the transplant of the anti-sodomy laws into Uganda. The lack of case law and the aggravated homophobic ideology in the normative realm that caused the enactment of the Act (an intensified form of the anti-gay laws) demonstrates how the anti-sodomy laws did not operate in the same way they did in the United Kingdom. This supports the idea that legal transplants produce an unpredicted effect when they move from one legal environment to another. Hence, despite there being a legal transplant of the rights based model into Uganda, there is no certainty that the laws will operate in the same way that they do in other Western countries. There is no assurance that it will secure protection for the LGBTQ community as it is very likely that the homophobia in the social realm would continue to prevail.

Consequently, it can be argued that instead of legally transplanting LGBTQ rights into Uganda, an alternative approach to comparative law should be used to legally reform the antisodomy laws, which takes into account the social and political factors surrounding these antigay laws.

\section{WESTERN REACTIONS TO THE ACT: THE POLITICAL AND SOCIAL IMPLICATIONS}

As the article has already highlighted, the Act attracted a great amount of negative attention from Western countries due to the fact that it violates their rights-based model protecting homosexuality. ${ }^{97}$ Leaders of various Western countries spoke publicly about their dislike for the Act and the values it represents. Former President Obama spoke about the Act stating that

\footnotetext{
94 George Mousourakis, 'How Comparative Law Can Contribute to the Development of a General Theory on Legal Evolution’ (2007-2008) 14 Tilburg Law Review 272, 282.

95 Gunther Teubner, 'Legal Irritants: Good Faith in British Law or How Unifying Law Ends up in New Divergences' (1998) 61 Modern Law Review 11, 12.

${ }^{96}$ ibid.

${ }^{97}$ Makua Mutua, 'Sexual Orientation and Human Rights: Putting Homophobia on Trial' in Sylvia Tamale (ed), African Sexualities (Pambazuka Press 2011) 458.
} 
'[the Act] will be a step backward for Ugandans and reflect poorly on Uganda's commitment to protecting the Human Rights of its people.' 98 Obama then went on to say that 'enacting this legislation will complicate our valued relationship with Uganda' ${ }^{99}$ This statement implies that were the legislation legitimised and the right to be homosexual in Uganda was infringed, then the economic relationship between the United States of America and Uganda would be jeopardised. Obama was not the only world leader to make these types of threats. David Cameron, also spoke on the legislation, stating those receiving aid should 'adhere to proper human rights'. ${ }^{100}$ Furthermore, Norway and Denmark also threatened to cut legal aid to Uganda were the bill enacted. ${ }^{101}$

It is plausible that these Western reactions were due to the fact that the legalisation of homosexuality in these countries saw their recognition as human rights, for example under the right to private and family life. ${ }^{102}$ However, the fact that Uganda has not seen the legalisation of homosexuality means that it is not yet viewed as a citizen right within the country. The reaction fails to take into account the social and political factors surrounding the Act, and the leaders of certain Western Countries sought to use power dynamics to influence the promotion of gay rights, which arguably does more harm than it does good for the LGBTQ community in Uganda. The reason why this reaction was injurious to the LGBTQ movement in Uganda is better explained through an examination of the social and political factors surrounding the Act.

\section{The Social and Political Factors surrounding the Act}

Regarded from a doctrinal standpoint, the Act proved to be a very difficult piece of legislation to implement. The lack of case law in the prosecution of homosexual couples under the already existing colonial anti-gay laws indicates the difficulty in providing evidence to prove homosexual intercourse has occurred between two consenting adults. It is conceivable that, had the legality of the Act not been challenged, prosecutors in the courts would have faced the same difficulties. Furthermore, as the petition evidently indicated, most of the provisions contained in the Act were unconstitutional. Therefore, in the event the Act was not declared null and void, any convictions secured under the Act would likely have been challenged in constitutional

98 'Ugandan Anti-Gay Law is a Huge Step Backwards Says Barack Obama' (2014) $<$ https://www.theguardian.com/world/2014/feb/16/uganda-anti-gay-law-barack-obama> accessed 21 March 2017. 99 ibid.

100 'Uganda Fury at David Cameron Aid Threat Over Gay Rights' (2011) <http://www.bbc.co.uk/news/worldafrica-15524013> accessed 21 March 2017.

${ }^{101}$ Martin Plaut, 'Uganda Donors Cut Aid After President Passes Anti-gay Law' (2014) $<$ https://www.theguardian.com/global-development/2014/feb/25/uganda-donors-cut-aid-anti-gay-law $>$ accessed 21 March 2017.

${ }^{102}$ Convention for the Protection of Human Rights and Fundamental Freedoms (European Convention on Human Rights, as amended) (ECHR) art 8. 
courts. In light of these doctrinal disadvantages, it can be argued that the Act was a political tool and as such it is necessary to analyse what the Ugandan government sought to achieve politically with its enactment.

Stella Nyanzi and Andrew Karmagi offer answers to this question in their article titled 'The social political dynamics of the anti-homosexuality legislation in Uganda' ${ }^{103}$ They use ethnographic fieldwork as the basis of their arguments and as lecturers at the Makerere University (the State University of Uganda) they provide an 'emic critique' 104 of the Act which proved to be very useful as the majority of the literature surrounding the Act comes from critics outside of Uganda. ${ }^{105}$ Furthermore, Nyanzi is a LGBTQ activist, ${ }^{106}$ which reduces the risk of bias in favour of the Ugandan government as she is someone who seeks to promote LGBTQ rights. The writers argue it is not possible to analyse the Act without reflecting on "the wider national political dynamics of governance and democracy." 107 They write that "Legacies of colonial laws aside, scholars associate homophobia with two main factors- conservative traditional culture and dominant religious interpretations". ${ }^{108}$ Thus, the Act was a way in which the politicians sought to gain support from the Ugandan people as traditional culture and religion are normative authorities in the Ugandan society and appealing to them would appeal to the Ugandan people. This further emphasises the importance of normative values in a society.

The President of Uganda was one of the main politicians who sought to use the Act as a 'bargaining chip'109 for support of the Ugandan people. However, he was in a difficult position as he had to maintain the support of the Ugandan people whilst at the same time trying not to offend the international human rights community as this would negatively affect the relationship Uganda had with aid donors. This offers an alternative explanation as to why the ascension of the Act was stalled. However, in light of the threats issued by the aid donors Museveni was left with a clear choice: Western aid or the prevalent normative values of the Ugandan people. He chose the normative values and this won him increased support within the country. Nyanzi and Karamagi argue that his support for the Act in spite of the Western threats not to enact the legislation 'reiterated Uganda's sovereignty, thereby building solidarity with

\footnotetext{
${ }^{103}$ Stella Nyanzi \& Andrew Karamagi (n 26).

104 ibid.

105 ibid.

${ }^{106}$ English Pen International, "Pen talks to Prominent Ugandan Academic and Activist Stella Nyanzi" (2017) $<$ http://www.pen-international.org/newsitems/pen-talks-to-prominent-ugandan-academic-and-activist-stellanyanzi/> accessed 6 February 2018.

${ }^{107}$ Nyanzi \& Karamagi (n 26).

108 ibid.

109 ibid.
} 
the other anti-colonialists and anti neo-imperialist opponents of homosexuality particularly in Africa.' ${ }^{110}$

Uganda's Speaker of Parliament, Rebecca Kadaga, also depicted the Act as a protection of Uganda's sovereignty. During the $127^{\text {th }}$ Inter-Parliamentary Union's Assembly, Canada's former Minister of Foreign Affairs, John Baird, criticised the Act and the parliamentarians entertaining it. ${ }^{111}$ Kadaga rebutted stating that 'If homosexuality is a value for the people of Canada, they should not seek to force Uganda to embrace it. We are not a colony or protectorate of Canada... Please respect our sovereign right, our cultural values and societal norms'.112 Following these statements, the Speaker was greeted by a cheering crowd upon her arrival back from the Assembly, ${ }^{113}$ furthermore, she gained support from majority of the Members of Parliament as the Parliamentary press statement on the issue stated she "clarified the Uganda Parliament's stand on Homosexuality." 114 Considering that Members of Parliament are elected representatives of wider Uganda it can be deduced from these reactions that the speaker's rebuttal gained her support from majority of the Ugandan people. Her coupling of homophobia with sovereignty perpetuated the notion that the Act was a symbol of nationalism which in turn exacerbated the homophobic attitudes present in Uganda. Thus, instead of helping the LGBTQ movements, the Foreign Minister's criticisms had an adverse effect.

Sylvia Tamale, a lecturer at Makerere University, also presents the argument that the Act was used as a political tool to gain the support of the Uganda people. She points out that the re-criminalisation of homosexuality in Uganda was one example of a 'homophobic upsurge... sweeping across the African continent'. ${ }^{115}$ She writes that 'The homophobic gusts blow amidst rising inflation, high unemployment, corruption repression and increased hopelessness among the populace.' ${ }^{116}$ She argues that what is similar in the African countries that were pushing for tighter legislation around homosexuality was that the political leaders

\footnotetext{
110 ibid.

111 ibid.

112 'Speaker Clarifies Uganda Parliament's Stand on Homosexuality' (2015) $<$ http://www.parliament.go.ug/new/index.php/about-parliament/parliamentary-news/124-speaker-clarifiesuganda-parliament-s-stand-on-homosexuality> accessed 29 January 2017.

113 Yasiin Mugerwa, 'Kadaga, Canadian Minister in Gay Row' $<$ http://www.monitor.co.ug/News/National/Kadaga--Canadian-minister-in-gay-row/688334-1594430t0reff/index.html > accessed 27 March 2017.

114 'Speaker Clarifies Uganda Parliament's Stand on Homosexuality' (n 112)

115 Sylvia Tamale, 'Confronting the politics of nonconforming sexualities in Africa' (2013) 5 African Studies Review 32, 39.

116 ibid.
} 
driving the re-criminalisation were leaders who had overstayed power. Therefore, they tried to use homophobic laws as a 'political distraction' ${ }^{117}$ from other problems faced by their nations.

This was evident in the case of Uganda. The Anti-Homosexuality bill was proposed in 2009, two years before the presidential elections of Uganda, elections that would see President Museveni enter his $25^{\text {th }}$ year as president. There was a myriad of human right violations surrounding these elections, such as allegations of rigging, corruption and abuse of media freedoms, ${ }^{118}$ and whilst activists in Uganda sought to appeal to the International community regarding these violations they failed to gain a response. ${ }^{119}$ However, the fact that some Western governments did respond to the Anti-homosexuality bill with threats of cutting aid ${ }^{120}$ shows that the bill was successful in its role as a political diversion. Furthermore, the decision to cut aid arguably alienated the LGBTQ community even more as it suggests that the needs of the LGBTQ community are more important than any other groups in society. Several African social justice activists, including some from Uganda, argued this point in a statement made in October 2011. They wrote:

The imposition of donor sanctions may be one way of seeking to improve the human rights situation in a country but does not, in and of itself, result in the improved protection of the rights of LGBTI people... in a context of general human rights violations where women are almost as vulnerable as LGBTI people, or where health and food security are not guaranteed for anyone, singling out LGBTI issues emphasises the idea that LGBTI rights are special and hierarchically more important than others. It also paradoxically has the effect of supporting, rather than counter acting the vicious notion that homosexuality is "un-African" and a Western-sponsored "idea" and that countries like the UK will only act when "their interests" have been threatened. ${ }^{121}$

Ryan Richard Thoreson makes an argument similar to that of Tamale and the African social justice activists mentioned above. Like Tamale, he examines the 'wave of Homophobia'122 among different African countries. However, rather than drawing on their similarities,

\footnotetext{
117 ibid.

118 'World Report 2011: Uganda' https:/www.hrw.org/world-report/2011/country-chapters/uganda> accessed 28 March 2017.

119 Tamale (n 115).

${ }^{120}$ Plaut (n 101).

${ }^{121}$ Sokari, 'Statement of African Social Justice Activists on the decision of the British Government to Cut Aid to African Countries that Violate the Rights of LGBTI People in Africa' (2009) http://www.blacklooks.org/2011/10/statement-of-african-social-justice-activists-on-the-decision-of-the-britishgovernment-to- $\% \mathrm{E} 2 \% 80 \% 9 \mathrm{Ccut}-\mathrm{aid} \% \mathrm{E} 2 \% 80 \% 9 \mathrm{D}$-to-african-countries-that-violate-the-rights-of-lgbti-peoplein-africa/> accessed 17 February 2017.

122 Ryan Richard Thoreson, 'Troubling the waters of a 'wave of homophobia': Political economies of anti-queer animus in sub-Saharan Africa' (2014) 17 (1/2) Sexualities 23, 24.
} 
Thoreson distinguishes between different homophobic incidents that occurred in Africa between 2009-2012. These include the Anti-homosexuality bill in Uganda, the arrest of a homosexual couple in Malawi and the increased anti-LGBTQ persecution in Senegal. ${ }^{123} \mathrm{He}$ argues that the political economies surrounding each of these events should be examined individually and a nuanced response should be asserted in globalised campaigns. ${ }^{124}$ As the paper has already mentioned, there are social and political factors that encourage homophobia in Uganda. It can be argued that challenging these factors would have been more beneficial to the endorsement of LGBTQ rights than generic donor sanctions or the threat thereof. This argument was made by Martin Loughlin when he sought to examine the development of the rights movement in the latter half of the twentieth century. ${ }^{125}$

\section{The Politics of Human Rights and the Bias in Universalism}

In the book, 'Swords and Scales, Martin Loughlin writes:

the rights movement can be understood as an evolutionary process of generalization (as greater numbers of political claims are expressed in the language of rights), institutionalization (as such claims increasingly acquire recognition in positive law), collectivization (as claims extend beyond the abstract individual to embrace social groups), and internationalization (as rights discourse enters the domain of international relations). ${ }^{126}$

Whereas the LGBTQ rights movement in Western countries underwent all these processes, the same cannot be said for LGBTQ rights in Uganda. As the section has just highlighted, the political narrative in Uganda supports homophobic attitudes. Hence, it is reasonable to assert the LGBTQ rights movement in Uganda is still trying to curb the first aspect which is the recognition of homosexuality as a political claim. Rights arguably have an intrinsically political nature, therefore, if they are ever to be promoted then they must first be promoted at a social level. Loughlin writes that 'Rights are local, historically-rooted claims not fixed universals'. ${ }^{27}$ It can be argued that some Western countries take for granted the importance of the first aspect of generalisation in the promotion of LGBTQ rights. As is evidenced by some Western countries' reactions to the Act, there was an attempt to use international relations to influence the movement of LGBTQ rights. However, in doing so, they arguably exude a moral

\footnotetext{
123 ibid.

124 ibid.

125 Martin Loughlin, "Swords and Scales: An Examination of the Relationship Between Law and Politics" (OUP 2000) 198.

126 ibid 208 .

127 ibid 203.
} 
imperialism. This moral imperialism then becomes detrimental to the LGBTQ rights movement as it tends to cause confrontational effects amongst the patriotic members of non-Western societies.

On the other hand, it can be argued the endorsement of human rights should not have to go through the processes mentioned by Loughlin above. This is because they are rights that should arguably pertain to every single individual in the world simply because the individual is a human. ${ }^{128}$ However, it is essential to have regard for how such universal rights are introduced into societies where they did not exist before. Radical universalism is the notion that culture and social norms are completely irrelevant when it comes to the validity of human rights. ${ }^{129}$ Thus in situations where universal rights are being introduced in societies where they previously did not exist, an exponent of the theory would argue that the cultural norms of that society are irrelevant. This is arguably the stance that some Western countries took in their response to the Act. However, in taking this radical universal approach they are essentially ordering their own moralistic views above the societal opinions of the people of Uganda.

Jack Donnelly warns about this when he writes that 'In order to preserve complete universality for basic rights, the radical universalist must give absolute priority to the demands of the cosmopolitan moral community over all other ("lower") communities. This complete denial of ethical autonomy and self-determination is dubious at best.' ${ }^{130}$ This is not to argue that LGBTQ rights should not be recognised as universal rights because they are not supported by prevalent societal values in every society. However, when introducing universal rights to societies where they are not universally accepted, it is detrimental to ignore dominant cultural norms and values completely.

Gunter Frankenberg also warns about bias disguised as objectivity, albeit he does so in the context of comparative law. Firstly, he criticises the view taken by proponents of legal transplants who argue that the law is a functional entity that may displaced from one environment to the other. ${ }^{131}$ Thus he would disagree with the implementation of LGBTQ rights without regard to the social and political realm of the host environment. He argues that legal comparatists (including those who draft international treaties) purport to be objective observers

\footnotetext{
128 James D. Wilets 'From Divergence to Convergence? A comparative and International Law Analysis LGBTI Rights in the context of race and post-colonialism' (2010-2011) 21 Journal of Comparative and International Law 631,633 .

129 Jack Donnelly, 'Cultural Relativism and Universal Human Rights' (1984) 6 Human Rights Quarterly Review $400,400$.

130 ibid 400.

131 Gunter Frankenberg, 'Critical Comparisons: Re-thinking Comparative Law' (1985) 26(2) Harvard International Law Journal 440, 441.
} 
but are naturally influenced by their own legal culture and experience, thus ethnocentrism is inherent to their work. ${ }^{132}$ Noting that there is an essential othering that comes with the work of comparatists, he writes that:

The civil and common law still rule over the comparatists' world. And the individual as an abstract legal entity bestowed with rights and duties has been transplanted from the Western to almost every other legal culture. The law that "We" have dominates the law that "Others" have. ${ }^{133}$

However, like this paper, he argues that the fact of bias should not translate to an end to comparative legal studies. Comparative legal studies are important as they can arguably help prevent the repetition of historic tragedies. This because they allow one to compare and learn from legal histories. However, legal perspective should not be taken for granted in comparative legal studies and it can be argued that the notion of legal transfer allows for this as it places the burden on state actors of a recipient country to adopt laws. Therefore, this paper will argue that a legal transfer of LGBTQ rights is a more suitable approach to reforming anti-homosexual legislation in Uganda. This is because it takes into account the normative values of host countries when there is a transfer of law.

\section{The Legal Transfer of LGBTQ Rights}

Although some academics use legal transfers and legal transplants synonymously, ${ }^{134}$ this article will take the approach of Frankenberg and his exponents who make a clear distinction between the two notions. Central to the notion of legal transfers is the idea that the law is not autonomous from society, therefore, it directly contends the notion of legal transplants as postulated by Watson. ${ }^{135}$ Proponents of legal transfers shift the focus onto the recipients of the new laws as opposed to the transferability of the law itself and argue that the socio-political environment of the countries receiving the new laws should be examined before there is a transfer of the law. ${ }^{136}$ In order to explain how legal transfers work, Frankenberg uses the 'IKEA theory'. ${ }^{137} \mathrm{He}$ argues, that first the country of origin of the law must be identified. Then the law must be decontextualised and placed in an imagined IKEA warehouse where the said law is globalized;

\footnotetext{
132 ibid.

133 ibid 440, 442.

134 David Nelken, 'Comparativists and Transferability' in Pierre Legrand and Roderick Munday (eds), Comparative Legal Studies: Traditions and Transitions (Cambridge University Press 2003) 437

${ }^{135}$ Pierre Legrand, 'The Impossibility of Legal Transplants' (1997) 4 Maastricht Journal of European \& Comparative Law 111, 112

${ }^{136}$ John Gillespie \& Pip Nicholson, 'Taking the interpretation of legal transfers seriously: the challenge for law and development' in John Gillespie \& Pip Nicholson (eds) Law and Development and the Global Discourses of Legal Transfers (Cambridge University Press, 2012) 8.

${ }^{137}$ Frankenberg (n 131) 563, 571.
} 
following this, state actors may then import the law and re-contextualise it into their own host country. ${ }^{138}$ The notion does not allow for any external pressures but rather there is an emphasis placed on the need for the host countries adopting these new legal rules themselves, which is why this method is preferred above others.

Frankenberg uses the example of the French Declaration of 1789. He explains that if you strip the declaration of its political connotations and image as a "revolutionary project"139 then it is nothing more than 'the thing with rights'. ${ }^{140}$ This then allows it to be marketable in the IKEA warehouse as other countries are able to decide whether to implement this "thing with rights" into their own countries. Rather than implementing a product of French politics, they are implementing a 'context-neutral concept' ${ }^{141}$. It can be argued that LGBTQ rights are already in the global reservoir. This is because a number of countries have seen the assertion of LGBTQ rights in their legal systems without the use of external pressures. They have simply decided that equality in sexualised relationships would be beneficial to the citizens of their country and as such state actors have imposed laws that bring about this equality. One example is the legalisation of homosexuality in Canada. While implementing the bill that would decriminalise homosexuality in Canada, Pierre Trudeau, the Prime Minister of Canada at the time, endorsed a 'modernization of the country's laws through the separation of church and state'. ${ }^{142} \mathrm{He}$ did so because he was inspired by the impact of homosexual law reform in the United Kingdom. ${ }^{143}$ Therefore, the idea of separating religion and law in the context of sexual relationships was inserted into the IKEA warehouse when the UK decided to legalise homosexuality. Other countries did not apply pressure on Canada to legalise homosexuality, neither were there any international organisations advocating for it, Canada solely transferred the law to its own state and adapted it to its legal environment. It can be argued that Uganda should be afforded the same freedom and the implementation of LGBTQ rights should be resultant of the Ugandan government re-contextualising LGBTQ rights. Hence, state actors play a crucial role in the legal transfer.

Mauro Zamboni also emphasises the role of state actors when it comes to legal change. She writes that 'it has also been seen how the legal actors in the addressees' legal system play a central (though) monopolising role in integrating the global legal categories in the national

\footnotetext{
138 ibid.

139 ibid.

140 ibid.

141 ibid.

${ }^{142}$ Stuart Chambers, 'Pierre Elliot Tradeau and Bill C-150: A Rational Approach to Homosexual Acts, 1968-69' (2010) 57(2) Journal of Homosexuality 249,250.

143 ibid.
} 
or legal culture'. ${ }^{144}$ This section has demonstrated that political actors in Uganda depend on the normative authorities to gain their support. Therefore, if there were to be a change in the normative attitudes of the Ugandan people that advocated for equality in sexual relationships then it would lead to a change in the political sphere as politicians would use these attitudes to try and gain support. The Western reactions to the Act fail to acknowledge the crucial role of state actors in the legal change. Perhaps more diplomatic talks, as opposed to the use of power dynamics, would have been more effective in persuading state legal actors to oppose the Act.

\section{E. CONCLUSION}

To conclude, a retrospective analysis of the Act and the social and political factors surrounding it indicates that the contestation of localised normative attitudes and international laws is problematic to globalisation especially in the advocacy of LGBTQ rights. However, to ignore these normative attitudes would exacerbate homophobic ideology as it would perpetuate the notion of homosexuality being an import from the West. Thus, for LGBTQ rights to be endorsed in Uganda, one must challenge the normative attitudes before any attempts to challenge the legislation, whether it be colonial legislation or any new legislation that may be enacted by the state of Uganda.

However, this article has demonstrated the homophobic attitudes in Uganda were the product of colonialism, therefore it can be argued that the western pressures to enact laws that facilitate LGBTQ rights can be translated as these societies 'simply remedying the damage wrought by the advent of historically aberrational virulent homophobia associated with Judaism, Christianity and Islam imposed on large sections of the world through conquest or colonialism'. ${ }^{145}$ However, at what point will these countries be able to make laws without the dictation of Western countries? At what point will their normative attitudes be taken into consideration? When will their own legal development become a product of their own internal discourse? An analysis of legal transplants, legal transfers and legal pluralism has illustrated that in the context of anti-gay laws, the normative attitudes of a society cannot be ignored in the implementation of effective pro-LGBTQ laws. Western countries cannot keep molding the legal systems of former colonies. At some point, legal actors in these countries must develop the law for themselves.

144 Mauro Zamboni, 'Globalization and Law-Making: Time to Shift a Legal Theory Paradigm' (2007) 1 Legisprudence 125, 152.

${ }^{145}$ James D Wilets 'From Divergence to Convergence? A comparative and International Law Analysis LGBTI Rights in the context of race and post-colonialism' (2010-2011) 21 Journal of Comparative and International Law 631,633 . 
Therefore, any legal reform in the area of homosexuality must come from internal pressures as opposed to external pressures with the latter being more sensitive to and supportive of the former rather than working autonomously. There are arguably a few ways in which this can be achieved. As the paper has highlighted, politicians in Uganda appeal to conservative religious values as well as patriotism in order to sustain the homophobic normativity in Uganda. Additionally, they use the political tactic of disgust in order to alienate the LGBTQ community even further. The international community could arguably support efforts to challenge these tactics as opposed to trying to forcefully invoke a legal change. John C. Mubuganzi offers effective ways by which to challenge these pervasive homophobic attitudes. He writes that 'court action, political engagement and education is critical' ${ }^{146}$ in changing normative attitudes in Uganda which will ultimately change the law.

It can be argued that in relation to the court action approach, the petition demonstrated that the constitution does not carry the same weight as ubiquitous normative attitudes. This is true in a sense, however, it only speaks to the weight of the constitution in the making of laws, i.e. in the role of parliament. It does not speak to the weight of the constitution in the judiciary. In the case of Victor Juliet Mukasa \& Yvonne Oyo v Attorney General ${ }^{147}$ the courts upheld the citizens' rights to privacy above the anti-sodomy laws. This shows that contrary to what is widely perceived, there are some judges in Uganda who take a liberal approach to rights and are ready to uphold these citizens' rights over any other laws. The international community may assist in cases like these by, for example, creating programmes that provide legal aid.

Furthermore, as the paper previously highlighted, disgust can be combatted with education. The reason why many political and non-political actors can endorse homophobia is that they are able to take advantage of the ignorance surrounding homosexual relationships. Information surrounding same-sex relationships will arguably prove to be very beneficial in the promotion of LGBTQ laws and this is an area the international community may also assist in. Additionally, there are many political leaders in Uganda that advocate for LGBTQ rights and although these leaders are not part of the ruling party. By supporting their campaigns, the international community can help support LGBTQ rights. While further research is needed as to best methods of challenging homophobic ideology in Uganda, these are some suggestions of what may be a more productive approach.

\footnotetext{
146 John C Mubangizi, 'Protecting the Right to Freedom of Sexual Orientation: What can Uganda Learn from South Africa?' (2011) 22 Stellenbosch Review 330,349.

${ }^{147}$ Misc. Cause No. 246/06.
} 